Running Head: $\quad$ DESCRIPTIVE NORMS AND ENTREPRENEURSHIP

\title{
Performance-based vs. Socially supportive Culture: A Cross-national Study of Descriptive Norms and Entrepreneurship
}

\author{
Ute Stephan \\ Katholieke Universiteit Leuven \\ Department of Managerial Economics, Strategy and Innovation \\ Namsestraat 69, B-3000 Leuven, Belgium \\ Tel: +32(0)16 3267 00, Fax: +32 (0)16 326732 \\ Ute.Stephan@econ.kuleuven.be \\ Lorraine M. Uhlaner \\ Nyenrode Business Universiteit \\ Centre of Entrepreneurship \\ P.O. Box 130, 3620 AC Breukelen, The Netherlands \\ Tel: +31 (0) 34629 1546, Fax: +31 (0) 346291250 \\ 1.uhlaner@nyenrode.nl

\section{forthcoming in Journal of International Business Studies doi:10.1057/jibs.2010.14}

\begin{abstract}
Acknowledgements:
Data for this study were provided by the Global Entrepreneurship Monitor (GEM), which is a consortium of research teams representing more than 60 nations across the globe. Names of the members of national teams, the global coordination team, and the financial sponsors are published in the annual Global Entrepreneurship Monitor Reports, which can be downloaded at www.gemconsortium.org. We thank all the researchers and their financial supporters who made this research possible. We thank Niels Bosma, Jolanda Hessels, Martin Lukes, Mark Peterson, Ulrike Roesler, André van Stel and John Whitman for helpful comments to previous versions of this manuscript. The work of the first author on this paper was partly supported by the European Commission, Socio-economic Sciences and Humanities (grant agreement 217622). A previous version of this paper was presented at the Academy of Management Annual Meeting, August 8-11, 2008, Anaheim, CA, USA.
\end{abstract}

\footnotetext{
About the Authors

Dr. Ute Stephan received her Ph.D. in Natural Sciences/Psychology from the University of Marburg. She is a senior researcher at the Department of Managerial Economics, Strategy and Innovation, Catholic University Leuven, Belgium. Her research interests are entrepreneurship and organizational behaviour including cultural influences on entrepreneurship and entrepreneur's motivation and health. Email: Ute.Stephan@econ.kuleuven.be.

Dr. Lorraine M. Uhlaner received her Ph.D. in Organization Psychology from the University of Michigan, Ann Arbor, MI. She is Professor of Entrepreneurship at Nyenrode Business University, the Netherlands. Her research interests include entrepreneurship and family business topics, including the effects of culture and social capital. Born in the United States, she is a dual citizen of the US and the Netherlands. Email: 1.uhlaner@nyenrode.nl.
} 


\title{
Performance-based vs. Socially-supportive Culture: A Cross-national Study of Descriptive Norms and Entrepreneurship
}

\begin{abstract}
This paper is a cross-national study testing a framework relating cultural descriptive norms to entrepreneurship in a sample of 40 nations. Based on data from the GLOBE project, we identify two higher-order dimensions of culture - socially-supportive culture (SSC) and performance-based culture (PBC) - and relate them to entrepreneurship rates and associated supply-side and demand-side variables available from the Global Entrepreneurship Monitor. Findings provide strong support for a social capital/ SSC and supply-side variable explanation of entrepreneurship rate. PBC predicts demand-side variables, such as opportunity existence and the quality of formal institutions to support entrepreneurship.
\end{abstract}

Keywords:

Comparative entrepreneurship; national culture; GLOBE; descriptive norms; institutional theory; social capital 


\section{Performance-based vs Socially Supportive Culture: A Cross-national Study of Descriptive Norms and Entrepreneurship}

\section{INTRODUCTION}

The present research has two overarching objectives: to examine the relationship between culture and entrepreneurship rate and second to broaden our understanding more generally about how to define and operationalize culture in international business and cross-cultural management research. As such, this paper aims to make three contributions. First, the paper provides a fresh perspective regarding the key dimensions of national culture and their relevance. Using a reanalysis of the Global Leadership and Organizational Behavior Effectiveness (GLOBE) project data (House, Hanges, Javidan, Dorfman, \& Gupta, 2004), we identify two types of cultural descriptive norms, socially-supportive culture (SSC) and performance-based culture (PBC). Second, as an empirical study it enhances our understanding of the relationship between culture (measured by GLOBE data) and entrepreneurship and associated supply-side and demand-side variables available from the Global Entrepreneurship Monitor studies. Third, the empirical examination of SSC, in particular, confirms the previously hypothesized role of social capital for entrepreneurship at the national level of analysis (Fukuyama, 2001).

A recent review of 57 studies by Van Praag and Versloot (2007) supports previous views that entrepreneurship contributes to employment creation, productivity and economic growth, thus corroborating the relevance of entrepreneurship for the world's economies (Audretsch \& Thurik, 2001). In spite of this growing body of knowledge, determinants of national entrepreneurship rates are not well understood. Formal institutional conditions such as the regulatory and economic environment provide a limited explanation of cross-national variability of entrepreneurship rates (e.g., Bowen \& de Clercq, 2008; Djankov, La Porta, Lopez-de-Silanes, \& Sheiffer, 2002; Van Stel, Storey, \& Thurik, 2007). Past research suggests that culture may help to further explain such variability (Hayton, George, \& Zahra, 2002; Uhlaner \& Thurik, 2007). 
Culture can be understood on many levels of analysis (Hofstede, 2001). We focus on the nationallevel while recognizing country borders are imperfect boundaries for different societies. Although national culture as a form of informal institution is firmly established in the international business literature (Peng, Wang, \& Jiang, 2008), its proper conceptualization and measurement is still hotly debated (e.g., Fischer, 2008; Hanges \& Dickson, 2006; Hofstede, 2006; Javidan, House, Dorfman, Hanges, \& Sully de Luque, 2006; Maseland \& Van Hoorn, 2009; Peng, Nisbett, \& Wong, 1997). We adopt the view of culture as informal institutions - i.e., patterns or repetitions of common behaviors and what institutional theorists refer to as practiced codes of conduct - which structure societal interactions (Barley \& Tolbert, 1997; Hatch \& Cunliffe, 2006; North, 1991). A culture shapes the behavior of its members not so much by values as by providing a 'dominant logic of action', i.e. a repertoire of habits, skills and styles (Swidler, 1986). Building on these arguments, we focus on cultural descriptive norms vs. cultural values, to predict societal outcomes. In the cross-cultural psychology literature, cultural descriptive norms, referred to in the GLOBE project as cultural practices (House et al., 2004), are characteristic behaviors displayed by most people within a culture as observed by members of that culture (Fischer, 2006, 2008; Fischer et al., 2009;

Shteynberg, Gelfand, \& Kim, 2009). Individuals and organizations are likely to conform to these norms by repeating behaviors which are typical for their own societies, whether as conscious acts to gain social acceptance or as less conscious imitation of typical behavior (Cialdini \& Trost, 1998; Fischer, 2006; Powell \& DiMaggio, 1991; Shteynberg et al., 2009). The main focus of our research is to examine whether cultural descriptive norms (henceforth referred to as descriptive norms) explain cross-national differences in entrepreneurship rate and certain antecedent supply-side and demand-side variables.

\section{BACKGROUND}

\section{Entrepreneurship (Rate): Its Definition and Framework at the Societal Level}

As is common in other macro-level studies in entrepreneurship, we define entrepreneurship as the occupational choice to work for one's own account and risk (i.e., the self-employed and other business- 
owners) (Hébert \& Link, 1982; Wennekers, 2006). Using data from the Global Entrepreneurship Monitor, we include four indicators for entrepreneurship. First, we measure new business ownership rate (Gartner, 1989; Reynolds et al, 2005) as a dynamic indicator of entrepreneurship. Second, we measure established business ownership rate as a static indicator of entrepreneurship, treating it as a proxy for the sustainability of entrepreneurship (Bosma, Acs, Autio, Coduras, \& Levie, 2009). While new and established business owner rates measure the overall level of entrepreneurship, they do not capture the quality of entrepreneurship, e.g. economically- vs. independence-motivated, which appears to be associated with different economic consequences (Minniti, Bygrave, \& Autio, 2006; Uhlaner \& Thurik, 2007). We thus include independent new business owner rate as a quality of entrepreneurship indicator. Finally, researchers also find particularly positive economic effects of innovative entrepreneurship (Levie \& Autio, 2008; Wong, Ho, \& Autio, 2005). We thus measure innovative new business owner rate based on new products and markets as a second quality of entrepreneurship indicator (Bowen \& de Clercq, 2008; Koellinger, 2008; Verheul, Wennekers, Audretsch, \& Thurik, 2002). ${ }^{1}$

In both sociological and economic models of entrepreneurship, a variety of supply-side and demand-side variables are seen to influence entrepreneurship at the macro-level (e.g., Thornton, 1999; Verheul et al., 2002; Wennekers, Uhlaner, \& Thurik, 2002). Supply-side refers to the 'supply' of potential entrepreneurs in a society. In addition to objective measures of skills and aptitudes, other supply-side variables measure precursors of entrepreneurial motivation or intentions. In the present study, we examine entrepreneurial self-efficacy, i.e. the confidence in one's skills and abilities to start and run a firm, and the social desirability of entrepreneurship, i.e. the subjective norms or commonly held perceptions regarding the status and rewards of entrepreneurship in a given population (Arenius \& Minniti, 2005; Busenitz, Gomez, \& Spencer, 2000; Koellinger, 2008; Reynolds, Bygrave, \& Autio, 2004). Both variables are components of entrepreneurial motivation in various models of entrepreneurial intention (Krueger, 2000; Krueger, Reilly \& Carsrud, 2000). Past research confirms an association between new firm creation and 
success for both social desirability of entrepreneurship (Busenitz et al, 2000; Reynolds et al., 2004) and entrepreneurial self-efficacy (Rauch \& Frese, 2007; Koellinger, 2008).

Evolutionary and institutional perspectives on entrepreneurship (e.g., Aldrich \& Martinez; 2001; Baumol, Litan, \& Schramm, 2007; North, 1991) argue that in addition to supply-side variables, predicting entrepreneurship rates at the national level requires inclusion of the situational context. Demand-side variables refer to a broad range of such situational variables (Thornton, 1999; Verheul et al., 2002; Wennekers et al., 2002), including the existence of entrepreneurial opportunities (Leibenstein, 1968; Shane \& Venkataraman, 2000), the quality of general national institutions, as well as those institutions more specifically aimed to support entrepreneurship, and henceforth referred to as entrepreneurial framework conditions (Bosma et al., 2009; Bowen \& de Clercq, 2008; Djankov et al., 2002). Environmental framework conditions include government policies and regulation, quality of research and development activity, physical infrastructure and other formal support for new and high-growth firms (Levie \& Autio, 2008).

We take the view that the existence of entrepreneurial opportunities (henceforth, referred to as opportunity existence) is central to entrepreneurial activity and that opportunities can exist independently of the observer (Shane \& Venkataraman, 2000). At any given time and place, characteristics of governmental, social, economic, or technological environment (e.g., technological and demographic changes) may create differential opportunities for entrepreneurship. Formal institutions, in turn, including both general national institutions as well as entrepreneurial framework conditions are regarded to be the major determinant of opportunity existence (Levie \& Autio, 2008; Verheul et al., 2002). Empirical support for the role of entrepreneurial framework conditions in fostering higher national entrepreneurship rates is mixed (Bowen \& De Clercq, 2008; Klapper, Laeven \& Rajan, 2006; Levie \& Autio, 2008; Van Stel et al., 2007). Some of these findings may be due to differences in the way entrepreneurship is measured as well as the non-control for high multicollinearity amongst the different aspects of entrepreneurial framework conditions (see Aidis, Estrin \& Mickiewicz, 2009). 
The majority of past research on culture and entrepreneurship has adopted a supply-side perspective, especially examining cultural values which may influence individual preferences for entrepreneurship (e.g. Hayton et al., 2002). However, we also include key demand-side variables in our research framework, given the central role of demand-side variables in macro-economic theory of entrepreneurship and recent evidence that culture may influence them (e.g. Pryor, 2007). Before we further elaborate our research framework and hypotheses, we first discuss the concept and measurement of culture.

\section{Values vs. Descriptive Norms: Two Approaches to the Study of Culture}

A review of past research on national culture reveals two alternative approaches to the description of culture: values vs. descriptive norms (Hofstede, 2001; House et al., 2004). Of the two approaches, the values perspective is by far the dominant approach in international business and cross-cultural research (Shteynberg et al., 2009) and in particular to predict entrepreneurship rate (Hayton et al., 2002; Hofstede, Noorderhaven, Thurik, Uhlaner, Wennekers, \& Wildeman, 2004; Uhlaner \& Thurik, 2007; Wennekers, Thurik, Van Stel, \& Noorderhaven, 2007). The values perspective dates back to Weber's thesis that Protestant values foster entrepreneurial skills (Jackman \& Miller, 1998; Weber, 1930). More recently, the aggregate trait perspective argues that societies with more individualists have a larger supply of potential entrepreneurs and in turn, a higher rate of entrepreneurship (Davidsson \& Wiklund, 1997; Hayton et al., 2002). We argue nevertheless, in favor of measuring culture based on descriptive norms.

First, regarding measurement, in the values approach, a country's culture is typically represented by the mean aggregated individual scores of personal preferences or desires of that country's respondents (Hofstede, 2001). ${ }^{2}$ By contrast, to measure descriptive norms, respondents are asked to describe existing typical behaviors in their culture (Fischer, 2006, 2008; Fischer et al., 2009; House et al., 2004; Shteynberg et al., 2009). Convergence of respondents' descriptions is statistically established before aggregating scores to the societal level (Fischer, 2008; House et al., 2004). These differences suggest that descriptive norms are more appropriate for explaining societal outcomes, because in contrast to values, they directly 
refer to the aggregated level (e.g. national culture to predict national entrepreneurship rate) (Arthur, Bell, \& Edwards 2007; Fischer, 2008; Klein \& Kozlowski, 2000).

Second, regarding the meaning of values vs. descriptive norms, we argue that values might be logically considered only to be loosely related with entrepreneurial activity since people do not necessarily act in line with their expressed personal preferences (e.g., Verplanken \& Holland, 2002; Swidler, 1986; Wicker, 1969). By contrast, descriptive norms exert normative influence on the behavior of individuals within a culture (e.g., Fischer, 2006; Shteynberg et al., 2009). In support of these arguments, researchers find that values are only weakly and/or inconsistently related to societal-level outcomes as well as cultural descriptive norms (Fischer, 2006; House et al., 2004; Javidan et al., 2006; Peng et al., 1997; Van Oudenhoven, 2001). Inconsistencies are also found for research on entrepreneurship and values at the macro-level. For instance, while some studies find individualism, low power distance and low uncertainty avoidance to be associated with higher entrepreneurship rate, other studies find the opposite pattern (Hayton et al., 2002 for a review; Hofstede et al., 2004; Wennekers et al., 2007). By contrast, though not previously used to predict entrepreneurship rate, a growing body of research confirms the more general finding that descriptive norms predict various behaviors at different levels of analysis including the individual-level (Aarts \& Dijksterhuis, 2003; Fischer, 2006; Nolan, Schultz, Cialdini, Goldstein, \& Griskevicius, 2008; Smith \& Louis, 2008) and societal-level outcomes including national competitiveness and societal health (House et al., 2004; Javidan et al., 2006).

\section{Which Dimensions of Cultural Descriptive Norms?: A Two-Factor Higher-Order Solution}

The GLOBE project currently provides the only validated measures of descriptive norms (i.e., cultural practices) available for a wide range of countries (House et al., 2004). It identifies nine dimensions, all of which show satisfactory agreement indices and internal consistencies and which are corroborated by multilevel confirmatory factor analyses (House et al., 2004). These findings establish the appropriateness of using these dimensions for national-level analyses. ${ }^{3}$ However, high intercorrelations amongst the nine dimensions create a serious problem of multicollinearity when dimensions are used in 
the same model (also Smith, 2006). One solution, though not used in prior GLOBE research, is to create second-order factors of these dimensions which allows them to be combined in the same analysis and provides a more complete representation of culture.

The existence of second-order factors for the GLOBE dimensions is illustrated by Peterson and Castro (2006) using an approach they refer to as ILSA/CAS. ${ }^{4}$ We roughly replicate their analysis using seven of the original nine factors (House et al., 2004). ${ }^{5}$ We obtain a two-factor solution and label the two factors performance-based culture (PBC) and socially-supportive culture (SSC) (Table 1).

Insert Table 1 about here

As shown in Table 1, the $P B C$ factor is characterized by high positive loadings of future orientation, uncertainty avoidance and performance orientation and high negative loadings of in-group collectivism and power distance. Thus, $\mathrm{PBC}$ can be described as a culture that rewards individual accomplishments (vs. collective membership, family relationships, or position) and in which systematic, future-oriented planning is viewed as a key way to achieve high performance. At first glance, a high positive loading of uncertainty avoidance on the PBC factor is puzzling. However, the GLOBE index for uncertainty avoidance measures the degree to which a society uses rules, requirements and laws to enhance predictability of future events, and to avoid turmoil and instability (Venaik \& Brewer, 2010). Predictability, in turn, is a prerequisite for engaging in effective future-oriented behaviors such as planning or for doing business in general (House et al., 2004). Thus, a high loading of uncertainty avoidance is consistent with the content of PBC. Societies scoring high on PBC belong to the Anglo, Germanic Europe and Nordic Europe country clusters (House et al., 2004). Countries belonging to the Latin American, Latin and Eastern Europe cluster exhibit the lowest scores, and Confucian and Southern Asian countries score in the middle.

The $S S C$ factor is characterized by a high positive loading of humane orientation and a high negative loading of assertiveness. Humane orientation and assertiveness reflect opposing descriptive 
norms of peoples' interaction with and treatment of one another. While humane orientation refers to whether individuals are concerned about and sensitive towards others, friendly, generous, and tolerant of mistakes; assertiveness reflects whether people are dominant, assertive, and tough (House et al., 2004). Thus, we presume that descriptive norms of high humane orientation and low assertiveness characterize a positive societal climate in which people support each other. To this end, SSC is arguably a direct measurement of social capital as an 'instantiated informal norm that promotes co-operation' (Fukuyama, 2001:7), or in other words a descriptive norm based on repeated experiences of supportiveness and helpfulness. It is also in line with perhaps the earliest reference to social capital by Hanifan (1916:130) as 'goodwill, fellowship, sympathy and social intercourse' (also Woolcock \& Narayan, 2000). Societies scoring high on SSC are Southern and Confucian Asian as well as societies from the Anglo and Nordic Europe country cluster. Latin American societies score in the middle and societies from Germanic, Eastern and Latin Europe show largely low scores. ${ }^{6}$ Country scores are available from the authors.

\section{OVERALL RESEARCH FRAMEWORK AND HYPOTHESES}

The primary focus of the current study is to examine whether and how descriptive norms predict entrepreneurship rate as well as key demand-side (i.e., entrepreneurial framework conditions and opportunity existence) and supply-side variables (i.e., social desirability of entrepreneurship and entrepreneurial self-efficacy) commonly proposed and/or tested in macro-level entrepreneurship research (Bosma, et al., 2009; Levie \& Autio, 2008; Verheul et al., 2002; Wennekers, 2006). Macro-level entrepreneurship theory further suggests, but does not test, that these demand-side and supply-side variables mediate the relationship between culture and entrepreneurship rate (e.g. Levie \& Autio, 2008; Reynolds et al., 2005, Verheul et al., 2002; Wennekers, 2006). We present the hypotheses and rationale for performance-based culture (PBC) and socially-supportive culture (SSC) as independent variables, in turn; followed by a more general hypothesis regarding mediating effects of the supply-side and demandside variables. 


\section{Performance-Based Culture (PBC) and Entrepreneurship}

A PBC should provide a facilitative context for entrepreneurship, because such norms encourage and reward individual accomplishments and systematic planning to achieve high future performance. In this sense, we presume, first of all, that a PBC stimulates the 'supply-side', i.e. the overall quality of (potential) entrepreneurs in a particular culture. More specifically, and in line with the notion of personculture-fit or match (Rauch, Frese, \& Sonnentag, 2000; Tung, Walls, \& Frese, 2007), we propose that societies with a PBC will have higher entrepreneurship rates, because the prerequisites for successful entrepreneurship, such as high achievement orientation and the inclination to plan are likely to be more pervasive in such cultures. Extensive research and meta-analyses find achievement-orientation and systematic planning related to entrepreneurship, i.e. venture creation and success (e.g., Brinckmann, Grichnik, \& Kapsa, 2008; Delmar \& Shane, 2003; Collins, Hanges, \& Locke, 2004; Rauch \& Frese, 2007). Hence, we propose:

Hypothesis 1 . PBC is positively associated with national entrepreneurship rate.

Since entrepreneurship is a performance- and achievement-oriented activity (e.g., Collins et al., 2004; McClelland, 1976; Rauch \& Frese, 2007) and therefore consistent with the norms of a PBC, it would also appear logical to assume that entrepreneurship is perceived as socially desirable in a high PBC. We thus state:

Hypothesis 2. PBC is positively associated with the social desirability of entrepreneurship.

A PBC may also influence certain demand-side variables. A number of researchers argue and find that in general, societies tend to build institutions that are consistent with that society's norms (Baumol et al., 2007; Fukuyama, 2001; Pryor, 2007; Levie \& Autio, 2008; Licht, Goldschmidt, \& Schwartz, 2007). More specifically, we therefore expect a high $\mathrm{PBC}$ with its emphasis on prediction, efficiency and rewards based on actual individual accomplishments rather than status, to be associated with clear government regulations for start-up and transparent, fair and equal access to resources (Djankov et al., 2002). Finally, 
as mentioned earlier, efficient institutions, in turn, are regarded to be the major influence on the existence of entrepreneurial opportunities (Levie \& Autio, 2008; Verheul et al., 2002). We thus hypothesize:

Hypothesis 3. PBC is positively associated with a) more favorable national environmental framework conditions and b) higher opportunity existence; and

Hypothesis 4: Environmental framework conditions mediate the relationship between PBC and opportunity existence.

\section{Socially-Supportive Culture (SSC) and Entrepreneurship}

We assume, first of all, that entrepreneurs in an SSC are likely to receive more help and support in founding and running their enterprise than in non-SSCs, or in short that the higher social capital of SSCs will positively impact entrepreneurship. The social capital literature provides several explanations for the positive effects of SSC on new venture creation and economic growth, including the sharing of information (Adler \& Kwon, 2002), a reduced need for monitoring and formal control (Portes, 1998:10), and reduction in transaction costs due to a heightened tendency to cooperate voluntarily (Fukuyama, 2001). At a more micro-level, research on entrepreneurs' networks and on inter-organizational networks confirms that resources made available through networks, such as information, money, as well as emotional support are crucial for the successful founding and running of a firm (Aldrich, Rosen, \& Woodward, 1987; Bruederl \& Preisendoerfer, 1998; Burt, 1992; O’Donnell, Gilmore, Cummins, \& Carson, 2001; Uzzi, 1997). Taken together this research suggests that entrepreneurs are socially embedded in and dependent on their environment, and furthermore, that higher social capital/SSC would increase their chances of success by facilitating access to much needed resources. Hence we hypothesize,

Hypothesis 5. SSC is positively associated with national entrepreneurship rate.

Furthermore, a SSC likely positively affects supply-side antecedents of entrepreneurship, specifically entrepreneurial self-efficacy. Organizational-level research finds that a socially-supportive environment is positively associated with self-efficacy beliefs (Choi, Price, \& Vinokur, 2003; Choi \& 
Chang, 2009) as such an environment allows a person to experiment with new ways of doing things 'without fear of appraisal, and frequent and open exchanges of feedback' (Choi et al., 2003: 360; also Anderson \& West, 1998; Edmondson, 1999). This is also consistent with other research in developmental psychology (Schmitt-Rodermund, 2004) and organizational behavior (e.g., Baer \& Frese, 2003; Hunter, Bedell, \& Mumford, 2007) suggesting that a socially-supportive (family and organizational) context facilitates experimentation and entrepreneurial behavior. Thus, we propose

Hypothesis 6. A SSC is positively associated with higher self-efficacy beliefs.

\section{Mediating Effects of Supply and Demand Variables}

As stated in the introduction, macro-level entrepreneurship theory suggests that supply-side and demand-side variables influence entrepreneurship rates (e.g. Thornton, 1999) and may also mediate the influence of culture on entrepreneurship rates (e.g. Levie \& Autio, 2008; Verheul et al., 2002). Theories of motivation and empirical research confirm that supply-side variables, such as entrepreneurial self-efficacy and social desirability of entrepreneurship, influence entrepreneurship rates (e.g., Busenitz et al. 2000; Koellinger, 2008; Krueger, 2000; Reynolds et al., 2004). Coupled with arguments already made regarding the links between PBC and supply-side variables (Hypothesis 2) and SSC and supply-side variables (Hypothesis 6), we suggest that supply side variables mediate the relationship between culture and entrepreneurship rate. We thus state:

Hypothesis 7: Supply-side variables mediate the relationship between cultural descriptive norms (i.e. $\mathrm{PBC}$ and SSC) and entrepreneurship rate.

As outlined in the introduction past research consistently argues that demand-side variables influence entrepreneurship rate (e.g., Levie \& Autio, 2008; Verheul et al, 2002) - although research provides some mixed findings (e.g. Van Stel et al., 2007). Nevertheless, following the theoretical arguments that demand-side variables, such as opportunity existence and entrepreneurial framework 
conditions, influence entrepreneurship rate on the one hand, and our above arguments that PBC influences demand-side variables (Hypothesis 3) on the other hand, we propose:

Hypothesis 8: Demand-side variables mediate the relationship between PBC and entrepreneurship rate.

\section{National Wealth (GDP) as Control Variable}

National wealth, typically measured as gross domestic product per capita (GDP), has been found to link strongly and negatively with national entrepreneurship rates (Minniti et al., 2006; Wennekers, Van Stel, Thurik, \& Reynolds, 2005; Uhlaner \& Thurik, 2007). Because this relationship is likely due to economically-motivated business ownership in poor nations (Audretsch \& Thurik, 2001; Reynolds et al., 2004), we also control for the effect of poverty on entrepreneurship activity, furthermore by measuring independent new business owner rate as one of our dependent variables.

\section{METHOD}

\section{Sample}

Information for the variables used in this study is available for 40 countries. $^{7}$ These countries represent five continents: Africa (1 country), Asia (including four countries in the Middle East) (15 countries), Australasia (2 countries), the Americas: South (6) and North (3), and Europe (13). Four countries are post-communist. For most continents countries with the largest population and land mass are included (e.g. Australia, Brazil, China, India, U.S.).

\section{Variables}

Descriptive Norms. The two indices of cultural descriptive norms, performance-based culture $(P B C)$ and socially-supportive culture (SSC) are based on reanalysis of previously collected and widely published data by the GLOBE project (House et al, 2004) as explained previously. 
Entrepreneurship rates. All four entrepreneurship rates are based on data provided by the Global Entrepreneurship Monitor Adult Population Survey (Bosma et al., 2009). New business ownership rate, is based on the percentage of the population between 18 to 64 years of age, who actively manage a business that is between three and 42 months old and for which pay is received. Established business ownership rate, is based on the proportion of the same population who actively manage a business that is more than 42 months old (Reynolds et al., 2005). Moreover, we include two indicators reflecting the quality of entrepreneurship. Independent new business owner rate is calculated as that percentage of all adults (18 to 64) meeting the criteria for new business ownership as described above and also meeting the following two criteria: 1) they founded the business to exploit business opportunities (opportunity-based entrepreneurship) and 2) that their opportunity motive was based on being independent (vs. economic motive). The second quality of entrepreneurship indicator, innovative new business owner rate, is calculated as that percentage of the same group of adults meeting the criteria for new business ownership described above and in addition, 1) reporting that their product is new to ALL or to MOST customers; and b) reporting that few or no businesses offer the same product (also Koellinger, 2008).

Social desirability of entrepreneurship. Social desirability of entrepreneurship is based on the mean country scores for three items also from the Global Entrepreneurship Monitor Adult Population Survey (see Reynolds et al., 2004). The score for each item is computed as the percentage of the adult population (random half of all entrepreneurially active and half of those not active) agreeing that in their country: 1) most people consider starting a new business a desirable career choice; 2) you often see stories in the public media about successful new businesses; and 3) those successful at starting a new business have a high level of status and respect.

Entrepreneurial self-efficacy. Entrepreneurial self-efficacy is also based on responses of a random half sample of entrepreneurially active and inactive respondents from the Global Entrepreneurship Monitor Adult Population Survey (see Arenius \& Minniti, 2005; Koellinger, 2008). The score for this item 
is the percentage of respondents agreeing with the statement: Do you have the knowledge, skill and experience required to start a new business?

Entrepreneurial framework conditions. This index is calculated from the mean of country scores for seven subindices drawn from of the Global Entrepreneurship Monitor Expert Panel. The seven subindices reflect entrepreneurship-specific institutional conditions that enhance start-ups, including government policies, governmental regulations, research and development activity, physical infrastructure, services, intellectual property rights protection and formal support specifically for high-growth businesses. ${ }^{8}$ Though used separately in previous studies (Levie \& Autio, 2008), their high intercorrelations, their high loadings on one factor and high internal reliability $(\alpha=0.96)$ support the decision to combine them into one index.

Opportunity existence. This index refers to the prevalence of opportunities for entrepreneurship and is also taken from the Global Entrepreneurship Monitor Expert Panel (see Reynolds et al., 2004). The index is based on the aggregated mean expert evaluations per country (using a five-point disagree-agree scale) for the following statements 1) There are plenty of good opportunities for the creation of new firms; 2) There are more good opportunities for the creation of new firms than there are people able to take advantage of them; 3) Good opportunities for new firms have considerably increased in the past five years, 4) Individuals can easily pursue entrepreneurial opportunities, and 5) There are plenty of good opportunities to create truly high-growth firms.

National wealth (GDP). We use the Gross Domestic Product (GDP) per capita in purchasing power standards in million international dollars as a measure of national wealth. Data was obtained from the World Economic Outlook database provided by the International Monetary Fund (2009).

\section{Scale Development and Reliability}

The descriptive norm measures, PBC and SSC, were collected by the GLOBE project once for each country during the 1994-1997 period. The other measures are constructed by averaging available 
aggregated country data for the years 2005 to 2008 . Table 2 summarizes information on retest-reliability (average year-to-year stabilities) and Cronbach's Alpha internal consistency for multi-item indices. Testretest reliabilities range from 0.69 to 1.00 . Cronbach's Alpha reliabilities range from 0.60 to 0.96 . Reliabilities are satisfactory for all variables. Moreover, all variables, except for independent new business owner rate are normally distributed. Thus, the natural log of independent new business owner rate is used in all analyses (Hair, Anderson, Tatham, \& Black, 1998).

Insert Table 2 about here

\section{Data Analysis}

We perform multiple regression analyses controlling for GDP to test all five hypotheses. For all analyses, multicollinearity is tested using variance inflation factors (VIF) to avoid the risk of suppressor effects in multiple regression analyses (Hair et al., 1998). VIF scores are in all cases well below the normally recommended cut-off score of 10 (Hair et al., 1998). All VIF scores are below 2.4 except for Models $1 \mathrm{~b}, 2 \mathrm{~b}, 3 \mathrm{~b}$ and $4 \mathrm{~b}$ in Table 5 which include both entrepreneurial framework conditions and GDP (VIF=3.7). Eliminating GDP from these models reduces VIF scores with no substantial changes to the pattern and size of results. To test for mediation effects of supply- and demand-side variables, we use protocols described by Frazier, Tix, and Barron (2004) including the Sobel test. ${ }^{9}$ We also tested for potential interaction effects of SSC and PBC on all models presented in Tables 3 through 5 but found no significant interaction effects.

\section{RESULTS}

The zero-order correlations among the variables and their descriptive statistics are presented in Table 2. The two independent variables, PBC and SSC are unrelated $(r=0.01, \mathrm{~ns})$. In the remainder of this section, we report on results of tests of the hypotheses. 


\section{Effects of Performance-based Culture on Entrepreneurship Rate and Supply/Demand Variables}

Tests for total effects of $\mathrm{PBC}$ on all four entrepreneurship rates (Hypothesis 1) are presented in Table 3. Significant negative beta-weights for the relationship between $\mathrm{PBC}$ and new business owner rate $(\beta=-0.31, p<0.05)$ and between PBC and established business owner rate $(\beta=-0.28, p<0.05$, see Table 3, Models 1 and 3) become nonsignificant once GDP is included as a control (Table 3, Models 2 and 4). PBC is not related to independent or to innovative new business owner rate (Table 3, Models 5 through 8). Hypothesis 1 is therefore not supported.

Table 4 presents tests for effects of PBC on the supply-side variable, social desirability of entrepreneurship (Hypothesis 2) and the demand-side variables, entrepreneurial framework conditions and opportunity existence (Hypothesis 3a and 3b). As shown in Models 3 and 4, Table 4, Hypothesis 2 is not supported. Results support, however, the predictions of Hypotheses 3a and 3b (Table 4, Models 5 through 8), showing a positive relationship between both PBC and opportunity existence $(\beta=0.45, p<0.05)$ and between PBC and entrepreneurial framework conditions $(\beta=0.40, p<0.01)$.

Results support Hypothesis 4. We find a mediation effect of entrepreneurial framework conditions between PBC and opportunity existence (Sobel test, $Z=2.17, p<0.05$ ). The significant association of PBC with opportunity existence (Table 4, Model 5 and 6) turns non-significant when entrepreneurial framework conditions are included in the model $(\beta=0.23 \mathrm{~ns}$.). Results are robust when controlling for GDP. All analyses are available from the authors and are not shown in Tables due to space constraints.

Insert Table 3 and 4 about here

\section{Effects of Socially-supportive Culture on Entrepreneurship Rate and Supply/Demand Variables}

In line with Hypothesis 5, socially-supportive culture (SSC) is positively associated with all four entrepreneurship rates controlling for GDP (Table 3, Models 2, 4, 6, and 8); ranging from $\beta=0.37, p<0.05$ for new business owner rate to $\beta=0.50, p<0.01$ for innovative new business owner rate. However, results fail to support Hypothesis 6. Although the zero-order correlation between SSC and entrepreneurial self- 
efficacy is positive and significant $(r=0.33, p<0.05)$, this relationship drops to nonsignificance when GDP is included as shown in Model 2 , Table $4(\beta=0.19, \mathrm{~ns})$. Notably, SSC is significantly and positively related to social desirability of entrepreneurship (see Model 4, Table 4, $\beta=0.43, p<0.01$ ).

\section{Mediating Effects of Supply/Demand Variables}

Reviewing the results (Table 4, Models 1 to 4) and Table 5 (Models 1a, 2a, 3a, 4a) suggests a mediation effect of the two supply-side variables (entrepreneurial self-efficacy and social desirability of entrepreneurship) especially for the relationship between SSC and entrepreneurship rates. Additional analyses (not shown in tables), reveal that social desirability fully mediates the effect of SSC on all four entrepreneurship rates including new (Sobel test, $Z=2.11, p<0.05$ ), established (Sobel test, $Z=1.89, p<$ 0.10 ), independent (Sobel test, $Z=2.06, p<0.05$ ), and innovative new business owner rate (Sobel test, $Z=$ $1.72, p<0.10$ ) controlling for GDP. Although there is a weaker mediation effect between SSC and new as well as established business owner rate by way of entrepreneurial self-efficacy, this effect disappears when GDP is included, suggesting a less robust result. Hypothesis 7 is therefore partially supported.

Hypothesis 8 is not supported. The precondition for the hypothesized mediation of PBC's influence on entrepreneurship rates through demand-side variables is not met (see Frazier et al., 2004), since PBC is not significantly associated with entrepreneurship rates (see results for Hypothesis 1).

Insert Table 5 about here

\section{DISCUSSION}

This paper investigates how national culture, as defined and measured by the emerging concept of cultural descriptive norms, relates to national entrepreneurship rates and its preconditions. Beyond the specific results which enhance our understanding of a macro-level theory of entrepreneurship, this paper makes three contributions to the cross-cultural literature more generally. First of all, we identify two 
higher-order dimensions: performance-based culture (PBC) and socially-supportive culture (SSC), the latter dimension also providing a new, but methodologically and theoretically grounded operational definition of social capital at the national level. Second, our findings highlight that SSC, or social capital, is the aspect of culture that drives both the overall level and the quality of national entrepreneurship. In other words, SSC influences an important source of economic growth, productivity and employment (Van Praag \& Versloot, 2007). Third, though research using descriptive norms is advancing in other areas, this paper, to our knowledge, is the first study exploring the merits of a cultural descriptive norms (vs. values) approach to the topic of entrepreneurship.

\section{Initial Discussion and Interpretation of Results}

We review first the results for PBC. Contrary to our hypotheses, PBC does not predict entrepreneurship rates and neither is it linked with the social desirability of entrepreneurship. However, as hypothesized we find that PBC predicts two key demand-side variables, including entrepreneurial framework conditions and opportunity existence. Furthermore, as we hypothesized, entrepreneurial framework conditions indeed mediate the relationship between PBC and opportunity existence. Thus, a PBC goes hand-in-hand and may lead to the building of efficient formal institutions which in turn enhance entrepreneurial opportunities (e.g., Levie \& Autio, 2008). Lastly, PBC is also closely related to national wealth (GDP). Reviewing the zero-order correlations shows a strong and positive linkage between PBC, GDP and entrepreneurial framework conditions. This is consistent with prior research that finds performance-orientation to be closely related to economic variables (McClelland, 1976; Weber, 1930).

Furthermore, our results are consistent with other recent research reporting weak to negative relations of entrepreneurial framework conditions and entrepreneurship (Levie \& Autio, 2008; Van Stel et al., 2007). One explanation, drawing on the evolutionary perspective, is that efficient formal institutions while at the same time creating opportunities and access to resources for new firms also create increased competition both between new and larger, established firms as well as amongst new firms. Thus, with increasingly efficient institutions, new firms may actually get squeezed out, competing for resources and 
customers with existing firms (Aldrich \& Martinez, 2001; Swaminathan, 1996). By contrast our findings suggest that social capital, as evidenced by the friendliness and cooperativeness of a culture, may play a far more decisive role for entrepreneurship (also Fukuyama, 1995, 2001). More specifically, our study is the first to find empirical evidence on the national-level that social capital as captured by sociallysupportive culture (SSC) has a consistent positive effect on both the level of entrepreneurship (new and established business owner rates) as well as on the quality of national entrepreneurship (independent and innovative new business owner rates). These findings are furthermore consistent with the positive effects of social capital on the individual- or firm-level (Aldrich et al., 1987; Uzzi, 1997).

We find the predicted positive influence of SSC on entrepreneurial self-efficacy. In addition we find that SSC also positively influences the second supply-side variable, social desirability of entrepreneurship. This is in line with the general notion that culture influences entrepreneurship rates through the social desirability of entrepreneurship as, for example, presumed in macro-level entrepreneurship theory (e.g., Levie \& Autio, 2008; Reynolds et al., 2004) and in individual-level motivation research (Krueger, 2000; Lent et al., 2000). In explaining this result, we consider past research which finds societies with higher social capital are more inclusive and thus, more accepting of minority groups (Fukuyama, 2001; Uslaner, 2004). Though not typically seen as a minority, indeed, new business owners represent less than $5 \%$ of the overall population in most countries (Minniti et al., 2006).

While not hypothesized, we also find that SSC positively influences the existence of opportunities (a demand-side variable). However, this finding is in line with the notion that higher social capital will enhance the number of weak ties (Granovetter, 1973) among members of a population, thereby increasing the number of opportunities discovered (Burt, 1992). In further support, a recent study by Kwon and Arenius (2008) finds that social capital explains differences in entrepreneurial opportunity perceptions amongst would-be and existing entrepreneurs.

In a wider context our study also contributes to the ongoing re-interpretation of entrepreneurship as not so much an individualistic, self-interest driven phenomenon, but rather as an activity embedded in a 
social context. As such, the 'optimal' cultural context for entrepreneurship is not an individualistic, performance-based culture, but rather a socially-supportive culture, rich in social capital.

\section{Implications for Cross-Cultural Research on Culture, Institutional Theory and Social Capital}

Beyond testing a framework for predicting entrepreneurship rates, our research has several implications for a wider audience in the research areas of culture, institutional theory and social capital. First of all with respect to culture, we demonstrate the usefulness of conceptualizing and measuring culture through the emerging concept of cultural descriptive norms - a conceptualization of culture in line with recent research in international management, psychology and institutional theory (Fischer, 2006; Hatch \& Cunliffe, 2006; Javidan et al, 2006; Shteynberg et al., 2009). Given that descriptive norms reflect the behavioral patterns in a society, and thus serve as informal institutions, we have argued that cultural descriptive norms can be used to predict behavioral outcomes at the societal level (also House et al., 2004; Javidan et al., 2006). Our findings support this argument, i.e. both performance-based culture (PBC) and socially-supportive culture (SSC) are significantly related to various societal-level behavioral outcomes (entrepreneurship, national institutions and wealth). By examining supply- and demand-side variables and mediation effects, we moreover provide a theoretical rationale and build first empirical evidence on pathways through which descriptive norms could influence such societal-level behavioral outcomes.

Second, we identify a parsimonious set of two higher-order dimensions (Hofstede, 2006; Peterson \& Castro, 2006; Smith, 2006), namely PBC and SSC capturing the majority of variation (75\%) of seven of the nine first-order dimensions identified in the GLOBE project. By doing so, we provide a tool for measuring culture especially in cross-national studies where sample sizes limit the number of variables allowed in one model, while eliminating problems of multicollinearity. In addition to obtaining high reliability and independence for these higher-order dimensions, we find evidence for their criterion validity.

Third, past empirical research relating social capital to macro-level variables has been limited by measurement problems regarding social capital (Werner \& Spence, 2004). Commonly-used measures of 
social capital at the macro level, such as number and size of civic associations, capture the consequences of social capital rather than social capital itself (i.e. an informal norm supporting cooperation) (Fukuyama, 2001; Werner \& Spence, 2004). By contrast, SSC is a direct measure of social capital, which also arguably captures better the actual level of helpfulness derived from informal contacts between people - the socalled structural holes (Burt, 1992), which are key for entrepreneurial success (Uzzi, 1997).

\section{Strengths, Limitations and Directions for Future Research}

Taken as a whole, our results also point to a number of gaps in the current macro-level models on entrepreneurship which need to be explored in further research. Although supply-side and demand-side models of entrepreneurship are popular in macro-level theory, connections between a number of the variables are not yet tested, and tests of other links are inconclusive. Our study has made an attempt to address some of these linkages, especially previously unexamined intervening relationships between culture and entrepreneurship rate.

Analyzing culture's influence on four different entrepreneurship rates is a further strength of the current study. Our study was able to demonstrate that SSC is a robust predictor of both overall level and quality of entrepreneurship, thus further corroborating the fundamental importance of social capital for entrepreneurship as for instance suggested by Fukuyama (1995).

From a methodological perspective, a potential limitation of our study is its correlational nature, which is typical for the phenomenon researched. However, our study suggests a causal explanation of the results in three ways. First, we control for national wealth (GDP) as a possible alternative explanation of our findings. Second, we pay careful attention to the times of data collection, data on the predictor variable (culture) being gathered roughly ten years (1994-1997) before data on entrepreneurship and other dependent variables (2005-2008). We thereby overcome problems of temporal ordering that have plagued research on social capital (Jackman \& Miller, 1998). Finally, we use an independent data source for the culture variables, eliminating the risk of common method bias between the independent, control, and dependent variables. 
Repeating the analyses with a larger number of countries is certainly desirable, especially as African countries were underrepresented in our sample and economically-advanced countries somewhat overrepresented. Nevertheless, we are still able to include diverse countries with varying economic and political backgrounds across all continents and thereby suggest that the findings of this study have a high chance of being replicated in different samples.

\section{Practical implications}

The findings of our research have implications for policy makers interested in encouraging more widespread business ownership. First of all, in recent years, policy makers have concentrated on changing formal institutions to increase entrepreneurial opportunities and entrepreneurship rate. However, we find no relationship between entrepreneurial framework conditions and entrepreneurship rate, indicating that formal institutions alone may be hard pressed to stimulate new business ownership. Our findings corroborate those of Van Stel et al. (2007) in suggesting that a focus solely on creating efficient institutions to stimulate entrepreneurship is not warranted. On the other hand, although our findings suggest that SSC clearly has a positive relationship with entrepreneurship rate, encouraging cooperation norms may not be so simple, given the stability of culture. For instance, past research finds helpfulness norms, an important component of SSC, to be stable over a 20-year period (Jackman \& Miller, 1998). Taken together, these findings suggest that policy makers wishing to influence entrepreneurship in the long-term may have to address the basic social institutions influencing society, fostering cooperativeness and helpfulness through education institutions, via the media and/or the workplace.

The way in which culture is mediated by certain supply-side variables may well be more open to change. Thus, the importance of social desirability of entrepreneurship, especially, as a mediating variable, suggests the relevance of reviewing how the media and other institutions present entrepreneurs to the public. For instance, whereas the US media in the 1970's often presented entrepreneurs negatively (e.g. in popular soap operas such as Dallas), these images were later counterbalanced by nonfiction portrayals of successful (but honest) entrepreneurs such as in (Social) Entrepreneur-of-the-Year awards. 
By presenting successful entrepreneurs as positive role models, school and/or after school programs can also play an important role to convey that entrepreneurship is a desirable career choice and to enhance entrepreneurial self-efficacy through behavioral learning (Bandura, 1991). Similarly, programs teaching people concrete know-how to start their own firms will help to develop entrepreneurial self-efficacy.

Lastly, our findings have implications for ventures co-operating across national borders. Preparing entrepreneurs for cross-border cooperation e.g. by means of cultural training (Landis, Bennett \& Bennett, 2003), may be particularly helpful when people from low vs. high SSCs or PBCs are required to work together. One can imagine that their different behaviors and behavioral expectations, e.g. supportive vs. assertive and aggressive, could easily lead to disappointments or even open conflicts.

\section{CONCLUSION}

The implications of the current research are clear: Cooperation and social support (vs. competitive aggressiveness) may be the key lever to stimulate entrepreneurship rates worldwide. The empirical examination of findings regarding socially-supportive culture (SSC), in particular, confirms the hypothesized role of social capital for entrepreneurship at the national-level of analysis (Fukuyama, 1995, 2001), for the first time with a relatively large sample (40 countries). The robustness of our findings, even when controlling for national wealth and examining four different entrepreneurship rates, provides strong support for this statement. Thus in spite of the widespread assumptions regarding the importance of systematic planning and achievement orientation of successful entrepreneurs, nations with higher performance-based culture (PBC) do not necessarily generate more and higher quality entrepreneurship, even though they do tend to be wealthier and tend to have more efficient formal institutions.

Entrepreneurship aside, the paper presents a fresh way to view the definition and measurement of culture at the national-level, using two categories of cultural descriptive norms, PBC and SSC. The consistency and interpretability of the results suggests that both may prove useful dimensions to study other types of societal outcomes in future research. 


\section{NOTES}

${ }^{1}$ We refrain from using the Global Entrepreneurship Monitor's Total Entrepreneurial Activity index which combines the rates of nascent entrepreneurs and new business ownership rate, since we are interested in the prediction of actual behavior, i.e. setting up a new firm/running an established firm and not in claims that one is about to do so (i.e. nascent entrepreneurship).

${ }^{2}$ Another operational definition of values is to ask respondents to indicate what their society should be like (e.g., value measurement in the GLOBE project and the European Values Survey). This approach, however, is criticized for capturing a rather abstract notion of the desirable, i.e. people report on what they feel they ought to desire and not on what they actually desire (Smith, 2005).

${ }^{3}$ The GLOBE project surveyed matched samples of over 17,370 middle managers from 951 local companies and three industry sectors (food processing, finance, and telecommunications). A full description of the method and items can be found in House et al (2004) and at www.thunderbird.edu/wwwfiles/ms/globe/instruments.asp.

${ }^{4}$ ILSA/CAS stands for Individual-Level Scales, Aggregate/Create Aggregate-level Scales. This reflects Peterson and Castro's (2006) assumption that the GLOBE descriptive norms scales were created on the individual level of analyses and afterwards aggregated, i.e. the mean country scores per scale calculated (ILSA). These aggregated scores are then subjected to a second-order, country-level factor analyses (CAS). It is the CAS part that we essentially replicate in our paper, i.e. the second-order factor analyses on the mean country scores of the descriptive norm dimensions provided by GLOBE.

${ }^{5}$ We use the response-bias corrected scores provided by House et al. (2004). Due to high crossloadings, we drop institutional collectivism. Due to the lack of a clearly based hypothesis, we also drop the gender egalitarianism scale, which loads on a third factor. We repeated the factor analysis on the full sample of 60 societies that took part in the GLOBE project (House et al., 2004) and found a highly similar factor solution. 
${ }^{6} \mathrm{PBC}$ and SSC themselves may also be useful to delineate country clusters and future research might elaborate on this. Preliminary work by the authors using discriminant analyses shows that countries can be classified into four cultural groups with an accuracy of $88.2 \%$, according to high or low PBC and high or low SSC. Germanic cultures (House et al., 2004) score low on SSC but high on PBC. Conversely, Southern Asian cultures (and some Confucian Asian cultures) score high on SSC but relatively low on PBC. Nordic and Anglo cultures (House et al., 2004) score high on both dimensions, while Eastern and Latin European as well as Latin American cultures tend to score low on both dimensions.

${ }^{7}$ The countries include Argentina, Australia, Austria, Bolivia, Brazil, Canada, China, Colombia, Denmark, Ecuador, Egypt, Finland, Germany, Greece, Hong Kong, Hungary, India, Indonesia, Iran, Ireland, Israel, Italy, Kazakhstan, Malaysia, Mexico, The Netherlands, New Zealand, Philippines, Russian Federation, Singapore, Slovenia, South Africa, South Korea, Spain, Switzerland, Thailand, Turkey, United Kingdom, United States, and Venezuela. To obtain country scores for South Africa, Germany and Switzerland, country subgroup scores were combined using weighted means based on the proportion of a subgroup relative to that country's population.

${ }^{8}$ A detailed description of this index is available from the authors. We include the following entrepreneurial framework condition scales described in detail in Levie and Autio (2008): Policy, Regulations, Programs, R\&D-transfer, Physical infrastructure, as well as scales capturing intellectual property rights and high-growth businesses support and encouragement.

${ }^{9}$ Frazier et al (2004) outline that mediating effects exist when a) the predictor is significantly associated with the outcome when the mediator is not included in the model; b) the predictor is significantly associated with the proposed mediating variable and c) the mediating variable is associated with the outcome even when controlling for the effects of the predictor. Furthermore, mediation effects will lead to a drop in the weight of the predictor when the mediating variables are added to the model. The significance of the drop is tested with the Sobel test (Frazier et al., 2004), for which we used a $p<0.10$ cutoff criterion to offset the limited statistical power due to the small sample size. 


\section{REFERENCES}

Aarts, H., \& Dijksterhuis, A. 2003. The silence of the library: Environment, situational norms, and social behavior. Journal of Personality and Social Psychology, 84(1): 18-28.

Adler, P.S., \& Kwon, S.W. 2002. Social capital: Prospects for a new concept. Academy of Management Review, 27(1): 17-40.

Aidis, R., Estrin, S., \& Mickiewicz, T. M. 2009. Entrepreneurial Entry: Which Institutions Matter? CEPR Discussion Paper No. DP7278. Available at SSRN: http://ssrn.com/abstract=1405075.

Aldrich, H.E., \& Martinez, M.A. 2001. Many are called, but few are chosen: An evolutionary perspective for the study of entrepreneurship. Entrepreneurship Theory \& Practice, 25(4): 41-56.

Aldrich, H.E., Rosen, D., \& Woodward, B. 1987. The impact of social networks on business foundings and profit: A longitudinal study. In N. Churchill et al. (Eds.), Frontiers of Entrepreneurship Research 1987: 154 -168. Wellesley, MA: Center for Entrepreneurial Studies, Babson College

Anderson, N.R., \& West, M.A. 1998. Measuring climate for work group innovation: development and validation of the team climate inventory. Journal of Organizational Behavior, 19(3): 235-258.

Arenius, P., \& Minniti, M. 2005. Perceptual variables and nascent entrepreneurship. Small Business Economics, 24(3): 233-247.

Arthur, W., Bell, S.T., \& Edwards, B.D. 2007. A longitudinal examination of the comparative criterionrelated validity of additive and referent-shift consensus operationalizations of team efficacy. Organizational Research Methods, 10(1): 35-58.

Audretsch, D.B., \& Thurik, A.R. 2001. What's new about the new economy? Sources of growth in the managed and entrepreneurial economies. Industrial and Corporate Change, 10(1): 267-315.

Baer, M., \& Frese, M. 2003. Innovation is not enough: Climates for initiative and psychological safety, process innovations, and firm performance. Journal of Organizational Behavior, 24(1): 45-68.

Bandura, A. 1991. Social cognitive theory of self-regulation. Organizational Behavior and Human Decision Processes, 50(2): 248-287.

Barley, S.R., \& Tolbert, P.S. 1997. Institutionalization and structuration: Studying the links between action and institutions. Organization Studies, 18(1): 93-117.

Baumol, W.J., Litan, R.E., \& Schramm, C.J. 2007. Good capitalism, bad capitalism, and the economics of growth and prosperity. Yale University Press: New Haven.

Bosma, N., Acs, Z.J., Autio, E., Coduras, A., \& Levie, J. 2009. Global Entrepreneurship Monitor: 2008 Executive Report. Babson Park, MA, Santiago, Chile, and London, UK: Babson College, Universidad del Desarrollo, and London Business School. 
Bowen, H.P., \& De Clercq, D. 2008. Institutional context and the allocation of entrepreneurial effort. Journal of International Business Studies, 39(4): 747-767.

Brinckmann, J., Grichnik, D., \& Kapsa, D. 2008. Should entrepreneurs plan or just storm the castle? A meta-analysis on contextual factors impacting the business planning-performance relationship in small firms. Journal of Business Venturing, doi:10.1016/j.jbusvent.2008.10.007.

Bruederl, J., \& Preisendoerfer, P. 1998. Network support and the success of newly founded businesses. Small Business Economics, 10(3): 213-225.

Burt, R.S. 1992. Structural holes. The social structure of competition. Cambridge, MA: Harvard University Press.

Busenitz, L.W., Gomez, C., \& Spencer, J.W. 2000. Country institutional profiles: Unlocking entrepreneurial phenomena. Academy of Management Journal, 43(5): 994-1003.

Choi, J. N., \& Chang, Y.J. 2009. Innovation implementation in the public sector: An integration of institutional and collective dynamics. Journal of Applied Psychology, 94(1): 245-253

Choi, J. N., Price, R. H., \& Vinokur, A. D. 2003. Self-efficacy changes in groups: Effects of diversity, leadership and group climate. Journal of Organizational Behavior, 24(4): 1-16.

Cialdini, R.B., \& Trost, M.R. 1998. Social influence: Social norms, conformity, and compliance. In D. Gilbert, J. Fiske \& G. Lindzey (Eds.), The handbook of social psychology: 151-192. New York: McGraw-Hill.

Collins, C.J., Hanges, P. J., \& Locke, E.A. 2004. The relationship of achievement motivation to entrepreneurial behavior: A meta-analysis. Human Performance, 17(1): 95-117.

Davidsson, P., \& Wicklund, J. 1997. Values, beliefs and regional variations in new firm formation rates. Journal of Economic Psychology, 18(2-3): 179-199.

Delmar, F., \& Shane, S. 2003. Does business planning facilitate the development of new ventures? Strategic Management Journal. 24(12): 1165-1185.

Djankov, S., La Porta, R., Lopez-de-Silanes, F., \& Shleiffer, A. 2002. The regulation of entry. Quarterly Journal of Economics, 117(1): 1-35.

Edmondson, A. 1999. Psychological safety and learning behavior in work teams. Administrative Science Quarterly, 44(2): 350-383.

Fischer, R. 2006. Congruence and functions of personal and cultural values: Do my values reflect my culture's values? Personality and Social Psychology Bulletin, 32(11): 1419-1431.

Fischer, R. 2008. Multilevel approaches in organizational settings: Opportunities, challenges and implications for cross-cultural research. In F.J.R. Van de Vijver, D.A. Van Hemert, \& Y. Poortinga (Eds.) Individuals and Cultures in Multi-level Analysis: 173-196. Mahwah, NJ: Lawrence Erlbaum Associates.

Fischer, R., Ferreira, M.C., Assmar, E., Redford, P., Harb, C., Glazer, S., Cheng, B. S., Jiang, D.Y., Wong, C., Kumar, N., Kaertner, J., Hofer, J., \& Achoui, M. 2009. Individualism-collectivism as 
descriptive norms: Development of a subjective norm approach to culture measurement. Journal of Cross-Cultural Psychology, 40(2): 187-213.

Frazier, P.A., Tix, A.P., \& Barron, K.E. 2004. Testing moderator and mediator effects in counseling psychology. Journal of Counseling Psychology, 51(1): 115-134.

Fukuyama, F. 2001. Social capital, civil society and development. Third World Quarterly, 22(1): 7-20.

Fukuyama, F. 1995. Social capital and the global economy: A redrawn map of the world. Foreign Affairs, 74(5): 89-103.

Gartner, W.B. 1989. "Who is an entrepreneur?" is the wrong question. Entrepreneurship Theory \& Practice, 13(4): 47-68.

Granovetter, M.S. 1973. The strength of weak ties. American Journal of Sociology, 78(6): 1360-1380.

Hair, J.F., Anderson, R.E., Tatham, R.L., \& Black, W.C. 1998. Multivariate data analysis. Upper Saddle River, NJ: Prentice Hall.

Hanges, P. J., \& Dickson, M. W. 2006. Agitation over aggregation: Clarifying the development of and the nature of the GLOBE scales. Leadership Quarterly, 17(5): 522-536.

Hanifan, L. 1916. The rural school community center. Annals of the American Academy of Political and Social Science, 67(1): 130-38.

Hatch, M.J., \& Cunliffe, A.L. 2006. Organization theory: Modern, symbolic, and postmodern perspectives. Oxford, UK: Oxford University Press.

Hayton, J.C., George, G., \& Zahra, S.A. 2002. National culture and entrepreneurship: A review of behavioral research. Entrepreneurship Theory and Practice, 26(4): 33-52.

Hébert, R.F., \& Link, A.N., 1982, The entrepreneurs: Mainstream views and radical critiques. New York: Praeger.

Hofstede, G. 2001. Culture's Consequences: Comparing values, behaviors, institutions and organizations across nations. Thousand Oaks, CA: Sage.

Hofstede, G. 2006. What did GLOBE really measure? Researchers' minds versus respondents' minds. Journal of International Business Studies, 37(6): 882-896.

Hofstede, G., Noorderhaven, N.G., Thurik, A.R., Uhlaner, L.M., Wennekers A.R.M., \& Wildeman, R.E. 2004. Culture's role in entrepreneurship: Self-employment out of dissatisfaction. In T. Brown and J. Ulijn \&. (Eds.), Innovation, entrepreneurship and culture: The interaction between technology, progress and economic growth: 162-203. Cheltenham, UK: Edward Elgar.

House, R.J., Hanges, P.J., Javidan, M., Dorfman, P.W., \& Gupta, V. 2004. Culture, Leadership and Organizations: The GLOBE Study of 62 Societies. Thousand Oaks, CA: Sage.

Hunter, S. T., Bedell, K. E., \& Mumford, M.D. 2007. Climate for creativity: A quantative review. Creativity Research Journal, 19(1): 69-90. 
International Monetary Fund. 2009. World economic outlook database. Retrieved June, 30th, 2009 from http://www.imf.org/external/pubs/ft/weo/2009/01/weodata/index.aspx.

Jackman, R.W., \& Miller, R.A. 1998. Social capital and politics. Annual Review of Political Science, 1(1): 47-73.

Javidan, M., House, R.J., Dorfman, P.W., Hanges, P.J., \& Sully de Luque, M. 2006. Conceptualizing and measuring cultures and their consequences: A comparative review of GLOBE's and Hofstede's approaches. Journal of International Business Studies, 37(6): 897-914.

Klapper, L. Laeven, L., \& Rajan, R. 2006. Entry regulation as a barrier to entrepreneurship. Journal of Financial Economics, 82(3): 591-629.

Klein, K.J., \& Kozlowski, S.W.J. (Eds.). 2000. Multilevel theory, research and methods in organizations. San Francisco, CA: Jossey-Bass.

Koellinger, P. 2008. Why are some entrepreneurs more innovative than others? Small Business Economics, 31(1):21-37

Krueger, N.F. 2000. The cognitive infrastructure of opportunity emergence. Entrepreneurship Theory \& Practice, 24(3): 5-23.

Krueger, N. F. Reilly, Jr., M. D., \& Carsrud, A. L. 2000. Competing models of entrepreneurial intentions. Journal of Business Venturing, 15(5): 411-432.

Kwon, S.-W., \& Arenius, P. 2008. Nations of entrepreneurs: A social capital perspective. Journal of Business Venturing, doi:10.1016/j.jbusvent.2008.10.008

Landis, D., Bennett, J.M., \& Bennett, M.J. 2003. Handbook of intercultural training. Thousand Oaks: Sage.

Leibenstein, H. 1968. Entrepreneurship and development. The American Economic Review, 58(2): 72-83.

Lent, R. W., Brown, S. D., \& Hackett, G. 2000. Contextual supports and barriers to career choice: A social cognitive analysis. Journal of Counseling Psychology, 47(1): 36-49.

Levie, J., \& Autio, E. 2008. A theoretical grounding and test of the GEM model. Small Business Economics, 31(3): 235-263.

Licht, A.N., Goldschmidt, C., \& Schwartz, S.H. 2007. Culture rules: The foundations of the rule of law and other norms of governance. Journal of Comparative Economics, 35(4): 659-688.

Maseland, R., \& Van Hoorn, A. 2009. Explaining the negative correlation between values and practices: A note on the Hofstede-GLOBE debate. Journal of International Business Studies, 40(3): 527-532.

McClelland, D. C. 1976. The achieving society. New York: Irvington.

Minniti, M., Bygrave, W., \& Autio, E. 2006. Global entrepreneurship monitor 2005 executive report. Babson Park, London and Kansas City, MO: Babson College, London Business School and Ewing Marion Kauffman Foundation. 
Nolan, J.M., Schultz, P.W., Cialdini, P.W., Goldstein, N.J., \& Griskevicius, V. 2008. Normative social influence is underdetected. Personality \& Social Psychology Bulletin, 34(7): 913-923.

North, D.C. 1991. Institutions. Journal of Economic Perspectives, 5(2): 97-112.

O’Donnell, A., Gilmore, A., Cummins, D., \& Carson, D. 2001. The network construct in entrepreneurship research: A review and critique. Management Decision, 39(9): 749-760.

Peng, K., Nisbett, R. E., \& Wong, N. Y. C. 1997. Validity problems comparing values across cultures and possible solutions. Psychological Methods, 2(4): 329-344.

Peng, M.W., Wang, D.Y.L., \& Jiang, Y. 2008. An institution-based view of international business strategy: a focus on emerging economies. Journal of International Business Studies, 39(5): 920936.

Peterson, M.F., \& Castro, S.L. 2006. Measurement metrics at aggregate levels of analysis: Implications for organization culture research and the GLOBE project. Leadership Quarterly, 17(5): 506-521.

Portes, A. 1998. Social capital: Its origins and applications in modern sociology. Annual Review of Sociology, 24(1):1-24.

Powell, W.W., \& DiMaggio, P.J. 1991. The new institutionalism in organizational analysis. Chicago: University of Chicago Press.

Pryor, F. L. 2007. Culture and economic systems. The American Journal of Economics and Sociology, 66(4): 817-855.

Rauch, A., \& Frese, M. 2007. Let's put the person back into entrepreneurship research: A meta-analysis on the relationship between business owners' personality traits, business creation, and success. European Journal of Work \& Organizational Psychology, 16(4): 353-385.

Rauch, A., Frese, M., \& Sonnentag, S. 2000. Cultural differences in planning-success relationships: A comparison of small enterprises in Ireland, West Germany, and East Germany. Journal of Small Business Management, 38(1): 28-41.

Reynolds, P.D., Bosma, N., Autio, E., Hunt, S., DeBono, N., Servais, I., Lopez-Garcia, P., \& Chin, N. 2005. Global entrepreneurship monitor: Data collection design and implementation 1998-2003. Small Business Economics, 24(3): 205-231.

Reynolds, P.D., Bygrave, W.D., \& Autio, E., 2004. Global entrepreneurship monitor 2003 executive report. Babson Park, London and Kansas City, MO: Babson College, London Business School and Ewing Marion Kauffman Foundation.

Schmitt-Rodermund, E. 2004. Pathways to successful entrepreneurship: Parenting, personality, early entrepreneurial competence, and interests. Journal of Vocational Behavior, 65(3): 498-518.

Shane, S., \& Venkataraman, S. 2000. The promise of entrepreneurship as a field of research. Academy of Management Review, 25(1): 217-226.

Shteynberg, G., Gelfand, M.J., \& Kim, K. 2009. Peering into the ,Magnum Mysterium' of culture: The explanatory power of descriptive norms. Journal of Cross-Cultural Psychology, 40(1): 46-69. 
Smith, P.B. 2005. Culture, leadership, and organizations: The GLOBE study of 62 societies. Journal of Cross-Cultural Psychology, 36(5): 628-630.

Smith, P.B. 2006. When elephants fight, the grass gets trampled: The GLOBE and Hofstede projects. Journal of International Business Studies, 37(6): 915-921.

Smith, J.R., \& Louis, W. R. 2008. Do as we say and as we do: The interplay of descriptive and injunctive group norms in the attitude-behaviour relationship. British Journal of Social Psychology, 47(4): $647-666$.

Swaminathan, A. 1996. Environmental conditions at founding and organizational mortality: A trial-by-fire model. Academy of Management Journal, 39(5): 1350-1377.

Swidler, A. 1985. Culture in action: Symbols and strategies. American Sociological Review, 51(2): 273286.

Thornton, P.H. 1999. The sociology of entrepreneurship. Annual Review of Sociology, 25(1): 19-46.

Tung, R.L., Walls, J., \& Frese, M. 2007. Cross-cultural entrepreneurship: The case of China. In J.R. Baum, M. Frese, \& R. Baron (Eds.), The Psychology of Entrepreneurship: 265-286. Mahwah, NJ: Lawrence Erlbaum Associates.

Uhlaner, L., \& Thurik, R. 2007. Postmaterialism influencing total entrepreneurial activity across nations. Journal of Evolutionary Economics, 17(2): 161-185.

Uslaner, E.M. 2004. Trust and social bonds: Faith in others and policy outcomes reconsidered. Political Research Quarterly, 57(3): 501-507.

Uzzi, B. 1997. Social structure and competition in interfirm networks: The paradox of embeddedness. Administrative Science Quarterly, 42(1): 35-67.

Van Oudenhoven, J.P. 2001. Do organizations reflect national cultures? A 10-nation study. International Journal of Intercultural Relations, 25(1): 89-107.

Van Praag, C.M., \& Versloot, P.H. 2007. What is the value of entrepreneurship? A review of recent research. Small Business Economics, 29(4): 351-382.

Van Stel, A., Storey, D., \& Thurik, R. 2007. The effect of business regulations on nascent and young business entrepreneurship. Small Business Economics, 28(2-3): 171 - 186.

Venaik, S. \& Brewer, P. 2010. Avoiding uncertainty in Hofstede and GLOBE. Journal of International Business Studies, doi:10.1057/jibs.2009.96.

Verheul, I., Wennekers, S., Audretsch, D., \& Thurik, R. 2002. An eclectic theory of entrepreneurship: Policies, institutions and culture. In D.B. Audretsch, A.R. Thurik, I. Verheul and S. Wennekers (eds.), Entrepreneurship: Determinants and policy in a European-US comparison: 1-71. Boston/Dordrecht: Kluwer.

Verplanken, B., \& Holland, R. W. 2002 Motivated decision making: Effects of activation and selfcentrality of values on choices and behavior. Journal of Personality \& Social Psychology. 82(3): 434-447. 
Weber, M. 1930. The protestant ethic and the spirit of capitalism. New York: The Citadel Press.

Wennekers, S. 2006. Entrepreneurship at country level: economic and non-economic determinants, ERIM Ph.D. Series Research in Management, 81, Erasmus School of Economics, Erasmus University Rotterdam, Rotterdam, NL.

Wennekers, S., Thurik, R., Van Stel, A., \& Noorderhaven, N. 2007. Uncertainty avoidance and the rate of business ownership across 21 OECD countries, 1976-2004. Journal of Evolutionary Economics, 17(2): 133-160.

Wennekers, A.W.E., Uhlaner, L.M., \& Thurik, A.R. 2002. Entrepreneurship and its conditions: A macro perspective. International Journal of Entrepreneurship Education, 1(1): 25-64.

Wennekers, S., Van Stel, A.J., Thurik, A.R., \& Reynolds, P. 2005. Nascent entrepreneurship and the level of economic development. Small Business Economics, 24(3): 293-309.

Werner, A., \& Spence, L. J. 2004. Literature review: Social capital and SMEs. In L. J. Spence, A. Habisch, \& R. Schmidpeter (Eds.), Responsibility and social capital: The world of small and medium sized enterprises: 7-24. New York, NY: Palgrave Macmillan.

Wicker A W. 1969. Attitudes versus actions: the relationship of verbal and overt behavioral responses to attitude objects. Journal of Social Issues, 25: 41-78.

Woolcock, M., \& Narayan, D. 2000. Social capital: Implications for development theory, research, and policy. The World Bank Research Observer, 15(2): 225-249.

Wong, P.K., Ho, Y.P., \& Autio, E. 2005. Entrepreneurship, innovation and economic growth: Evidence from GEM data. Small Business Economics, 24(3): 335-350. 
TABLE 1

Second-order factor solution of cultural descriptive norm dimensions ${ }^{\mathrm{a}}$

\begin{tabular}{|c|c|c|c|}
\hline & $\begin{array}{l}1 \text { - Performance-based Culture } \\
(\mathrm{PBC})\end{array}$ & $\begin{array}{l}2 \text { - Socially-supportive Culture } \\
\text { (SSC) }\end{array}$ & $h^{2}$ \\
\hline Future orientation & 0.90 & 0.10 & 0.82 \\
\hline Uncertainty avoidance & 0.91 & 0.04 & 0.82 \\
\hline Performance orientation & 0.79 & -0.10 & 0.63 \\
\hline Power distance & -0.70 & 0.28 & 0.57 \\
\hline In-group collectivism & -0.75 & -0.16 & 0.58 \\
\hline Humane orientation & 0.13 & -0.91 & 0.83 \\
\hline Assertiveness & 0.13 & 0.90 & 0.82 \\
\hline Variance explained (\%) & 49.67 & 25.00 & \\
\hline Cronbach's Alphab & 0.85 & 0.75 & \\
\hline \multicolumn{4}{|c|}{$h^{2}-$ Item communality (item variance explained by factors) } \\
\hline \multicolumn{4}{|c|}{${ }^{\text {a }}$ based on $N=40$ countries described in the methods section, Varimax rotation. } \\
\hline \multicolumn{4}{|c|}{$\begin{array}{l}{ }^{b} \text { The performance-based and socially-supportive culture scales are calculated as mean sum scales } \\
\text { on these results, after reverse coding negatively loading scales for factor } 1 \text {. For factor } 2 \text { scales were } \\
\text { d so that higher scores indicate higher humane orientation and lower assertiveness. }\end{array}$} \\
\hline
\end{tabular}


TABLE 2

Descriptive statistics and correlations ${ }^{a, b}$

\begin{tabular}{|c|c|c|c|c|c|c|c|c|c|c|c|}
\hline & 1 & 2 & 3 & 4 & 5 & 6 & 7 & 8 & 9 & 10 & 11 \\
\hline $\begin{array}{l}\text { 1. New business owner } \\
\text { rate }\end{array}$ & $(.93 /-)$ & & & & & & & & & & \\
\hline $\begin{array}{l}\text { 2. Established business } \\
\text { owner rate }\end{array}$ & $.88 * * *$ & $(.79 /-)$ & & & & & & & & & \\
\hline $\begin{array}{l}\text { 3. Independent new } \\
\text { business owner rate }(\ln )\end{array}$ & $.71 * * *$ & $.66 * * *$ & $(.83 /-)$ & & & & & & & & \\
\hline $\begin{array}{l}\text { 4. Innovative new } \\
\text { business owner rate }\end{array}$ & $.79 * * *$ & $.69 * * *$ & $.66^{* * *}$ & $(.71 /-)$ & & & & & & & \\
\hline $\begin{array}{l}\text { 5. Performance-based } \\
\text { culture }\end{array}$ & $-.31^{t}$ & $-.28^{t}$ & .18 & -.11 & $(-/ .85)$ & & & & & & \\
\hline $\begin{array}{l}\text { 6. Socially-supportive } \\
\text { culture }\end{array}$ & $.51 * * *$ & $.45^{* * *}$ & $.43 * *$ & $.50 * * *$ & .01 & $(-/ .75)$ & & & & & \\
\hline $\begin{array}{l}\text { 7. Entrepreneurial self- } \\
\text { efficacy }\end{array}$ & $.55^{* * *}$ & $.56 * * *$ & $.41 * *$ & $.34 *$ & -.21 & $.33 *$ & $(.82 /-)$ & & & & \\
\hline $\begin{array}{l}\text { 8. Social desirability of } \\
\text { entrepreneurship }\end{array}$ & $.64 * * *$ & $.57 * * *$ & $.48 * *$ & $.51 * * *$ & -.17 & $.52 * * *$ & $.45^{* *}$ & $(.69 / .60)$ & & & \\
\hline 9. Opportunity existence & .18 & .15 & $.29^{t}$ & $.31^{t}$ & $.45^{* *}$ & $.45^{* *}$ & .03 & $.36^{*}$ & $(.89 / .69)$ & & \\
\hline $\begin{array}{l}\text { 10. Entrepreneurial } \\
\text { framework conditions }\end{array}$ & $-.34 *$ & $-.27^{t}$ & .12 & -.10 & $.72 * * *$ & -.11 & $-.48 * * *$ & -.15 & $.46^{* *}$ & $(.94 / .96)$ & \\
\hline 11.GDP & $-.57 * * *$ & $-.43 * *$ & .03 & -.24 & $.64 * * *$ & $-.34 *$ & $-.44 * *$ & $-.41 * *$ & .12 & $.76^{* * *}$ & $(1.00 /-)$ \\
\hline MEAN & 5.43 & 8.21 & -.09 & .97 & 3.59 & 3.96 & 48.47 & 65.60 & 3.39 & 2.74 & $21,421.92$ \\
\hline SD & 3.95 & 4.46 & .67 & .74 & .43 & .35 & 13.17 & 9.19 & .31 & .42 & $13,458.65$ \\
\hline
\end{tabular}


TABLE 3

Hierarchical regression of descriptive norms on national entrepreneurship rates $\mathbf{I}^{\mathrm{a}}$

\begin{tabular}{|c|c|c|c|c|c|c|c|c|}
\hline & \multicolumn{2}{|c|}{$\begin{array}{l}\text { New business owner } \\
\text { rate }\end{array}$} & \multicolumn{2}{|c|}{$\begin{array}{l}\text { Established business } \\
\text { owner rate }\end{array}$} & \multicolumn{2}{|c|}{$\begin{array}{l}\text { Independent new } \\
\text { business owner rate }\end{array}$} & \multicolumn{2}{|c|}{$\begin{array}{l}\text { Innovative new } \\
\text { business owner rate }\end{array}$} \\
\hline & Model1 & Model 2 & Model 3 & Model 4 & Model 5 & Model 6 & Model 7 & Model 8 \\
\hline \multicolumn{9}{|l|}{ Descriptive norms } \\
\hline Socially-supportive culture & $.51 * * *$ & $.37 *$ & $.45^{* *}$ & $.38^{*}$ & $.42 * *$ & $.47 * *$ & $.50 * * *$ & $.50 * *$ \\
\hline Performance-based culture & $-.31 *$ & -.05 & $-.28^{*}$ & -.15 & .17 & .09 & -.12 & -.12 \\
\hline National Wealth (GDP) & & $-.41 *$ & & -.21 & & .13 & & .00 \\
\hline $\begin{array}{l}F \text {-value } \\
(d f 1, d f 2)\end{array}$ & $\begin{array}{l}10.34 * * * \\
(2,37)\end{array}$ & $\begin{array}{l}9.32 * * \\
(3,36)\end{array}$ & $\begin{array}{l}7.32 * * \\
(2,37)\end{array}$ & $\begin{array}{l}5.25^{* *} \\
(3,36)\end{array}$ & $\begin{array}{l}4.93^{*} \\
(2,37)\end{array}$ & $\begin{array}{l}3.36^{*} \\
(3,36)\end{array}$ & $\begin{array}{l}6.51 * * \\
(2,37)\end{array}$ & $\begin{array}{l}4.22^{*} \\
(3,36)\end{array}$ \\
\hline$R^{2}$ & $.36 * * *$ & $.44^{* *}$ & $.28 * *$ & $.30 * *$ & $.21 *$ & $.22 *$ & $.26^{* *}$ & $.26^{*}$ \\
\hline Adjusted $R^{2}$ & $.32 * * *$ & $.39 * *$ & $.24 * *$ & $.25^{* *}$ & $.17 *$ & $.16^{*}$ & $.22 * *$ & $.20^{*}$ \\
\hline$\Delta R^{2} \mathrm{GDP}$ & & $.08 *$ & & .02 & & .01 & & .00 \\
\hline
\end{tabular}

${ }^{\mathrm{t}} p \leq .10,{ }^{*} p \leq .05,{ }^{* *} p \leq .01,{ }^{* * *} p \leq .001$ (two-tailed), $N=40$

${ }^{a}$ standardized regression coefficients $(\beta$-weights) 


\section{TABLE 4}

Hierarchical regression of descriptive norms on supply-side and demand-side variables ${ }^{\mathrm{a}}$

\begin{tabular}{|c|c|c|c|c|c|c|c|c|}
\hline & \multicolumn{4}{|c|}{ Supply-side variables } & \multicolumn{4}{|c|}{ Demand-side variables } \\
\hline & \multicolumn{2}{|c|}{$\begin{array}{l}\text { Entrepreneurial } \\
\text { self-efficacy }\end{array}$} & \multicolumn{2}{|c|}{$\begin{array}{l}\text { Social desirability } \\
\text { of entrepreneurship }\end{array}$} & \multicolumn{2}{|c|}{$\begin{array}{l}\text { Opportunity } \\
\text { existence }\end{array}$} & \multicolumn{2}{|c|}{$\begin{array}{l}\text { Entrepreneurial } \\
\text { framework conditions }\end{array}$} \\
\hline & Model 1 & Model 2 & Model 3 & Model 4 & Model 5 & Model 6 & Model 7 & Model 8 \\
\hline \multicolumn{9}{|l|}{ Descriptive norms } \\
\hline Socially-supportive culture & $.33^{*}$ & .19 & $.52 * * *$ & $.43 * *$ & $.44 * * *$ & $.44 * *$ & -.09 & .06 \\
\hline Performance-based culture & -.21 & .04 & -.18 & -.01 & $.44 * * *$ & $.45^{*}$ & $.72 * * *$ & $.40 * *$ \\
\hline National wealth (GDP) & & $-.40^{t}$ & & -.26 & & -.01 & & $.51 * * *$ \\
\hline$F$-value & $3.36^{*}$ & $3.60^{*}$ & $7.98 * * *$ & $5.99 * *$ & $12.14 * * *$ & $7.88 * * *$ & $20.49 * * *$ & $23.54 * * *$ \\
\hline$(d f 1, d f 2)$ & $(2,37)$ & $(3,36)$ & $(2,37)$ & $(3,36)$ & $(2,37)$ & $(3,36)$ & $(2,37)$ & $(3,36)$ \\
\hline$R^{2}$ & $.15^{*}$ & $.23 *$ & $.30 * * *$ & $.33 * *$ & $.40 * * *$ & $.40 * * *$ & $.53 * * *$ & $.66 * * *$ \\
\hline Adjusted $R^{2}$ & $.11^{*}$ & $.17^{*}$ & $.26 * * *$ & $.28 * *$ & $.36^{* * *}$ & $.35 * * *$ & $.50 * * *$ & $.63 * * *$ \\
\hline$\Delta R^{2} \mathrm{GDP}$ & & $.08^{t}$ & & .03 & & .00 & & $.13 * * *$ \\
\hline
\end{tabular}

${ }^{t} p \leq .10, * p \leq .05, * * p \leq .01, * * * p \leq .001$ (two-tailed), $N=40$

${ }^{a}$ standardized regression coefficients $(\beta$-weights) 


\section{TABLE 5}

Hierarchical regression of descriptive norms, supply-side and demand-side variables on national entrepreneurship rates ${ }^{\text {a }}$

\begin{tabular}{|c|c|c|c|c|c|c|c|c|}
\hline & \multicolumn{2}{|c|}{$\begin{array}{l}\text { New business owner } \\
\text { rate }\end{array}$} & \multicolumn{2}{|c|}{$\begin{array}{l}\text { Established business } \\
\text { owner rate }\end{array}$} & \multicolumn{2}{|c|}{$\begin{array}{l}\text { Independent new } \\
\text { business owner rate }\end{array}$} & \multicolumn{2}{|c|}{$\begin{array}{l}\text { Innovative new } \\
\text { business owner rate }\end{array}$} \\
\hline & Model 1a & Model 1b & Model 2a & Model 2b & Model 3a & Model 3b & Model 4a & Model 4b \\
\hline \multicolumn{9}{|l|}{ Descriptive norms } \\
\hline Socially-supportive culture & .18 & $.31^{t}$ & .19 & $.34^{t}$ & .25 & $.45 *$ & $.34^{t}$ & $.39 *$ \\
\hline Performance-based culture & -.06 & -.14 & -.16 & -.22 & .08 & .07 & -.12 & -.21 \\
\hline National Wealth (GDP) & -.23 & $-.45^{t}$ & -.00 & -.24 & $.36^{t}$ & .13 & .13 & .03 \\
\hline Self-efficacy & $.22^{t}$ & & $.33 *$ & & $.34 *$ & & .12 & \\
\hline Social desirability of entrepreneurship & $.34^{*}$ & & $.29^{t}$ & & $.37 *$ & & $.32^{t}$ & \\
\hline Entrepreneurial framework conditions & & .12 & & .10 & & .04 & & -.05 \\
\hline Opportunity existence & & .08 & & .06 & & -.00 & & .24 \\
\hline $\begin{array}{l}F \text {-value } \\
(d f 1, d f 2)\end{array}$ & $\begin{array}{l}9.53 * * * \\
(5,34)\end{array}$ & $\begin{array}{l}5.62 * * * \\
(5,34)\end{array}$ & $\begin{array}{l}6.28 * * * \\
(5,34)\end{array}$ & $\begin{array}{l}3.11 * \\
(5,34)\end{array}$ & $\begin{array}{l}5.44 * * * \\
(5,34)\end{array}$ & $\begin{array}{l}1.92 \\
(5,34)\end{array}$ & $\begin{array}{l}3.68 * * \\
(5,34)\end{array}$ & $\begin{array}{l}2.82^{*} \\
(5,34)\end{array}$ \\
\hline$R^{2}$ & $.58 * * *$ & $.45 * * *$ & $.48 * * *$ & $.31 *$ & $.44 * * *$ & .22 & $.35 * *$ & $.29 *$ \\
\hline Adjusted $R^{2}$ & $.52 * * *$ & $.37 * * *$ & $.40 * * *$ & $.21 *$ & $.36 * * *$ & .11 & $.26^{* *}$ & $.19^{*}$ \\
\hline$\Delta R^{2}$ Supply-side variables ${ }^{\mathrm{b}}$ & $.15^{* *}$ & & $.18 * *$ & & $.23 * *$ & & .09 & \\
\hline$\Delta R^{2}$ Demand-side variables ${ }^{\mathrm{b}}$ & & .02 & & .01 & & .00 & & .03 \\
\hline
\end{tabular}

